\title{
EGYEDI PROJEKTVEZETÉSI ESZKÖZÖK ALKALMAZÁSI LEHETŐSÉGE A PROJEKTPROGRAMOK TELJESÍTÉSÉBEN
}

A projektportfóliók és projektprogramok teljesítésével foglalkozó szakirodalom, lényegében egyfajta általános szintú közelítésmódnak köszönhetốen, gyakorlatilag csak a programiroda, legfeljebb a tervezés információrendszerének kérdéskörét helyezi elốtérbe. Noha egy projektprogram lényegesen több mint a programot alkotó projektjeinek egyszerú halmaza, azért a programok elemei mégiscsak projektek. Minthogy az ördög pedig a részletekben van, így célszerú annak vizsgálata is, hogy az egyedi projektek kapcsán alkalmazott projektvezetési eszközök miként segíthetik elố a projektprogramok teljesítését és vezetésének hatékonyságát, így végsố soron a programok sikerességét. A szerzó ebben a tanulmányban kvalitatív kutatáson alapuló eredményekre támaszkodva rámutat azoknak az egyedi projektvezetési eszközöknek a programszintư alkalmazási lehetôségeire, amelyek döntően meghatározhatják a programok sikeres teljesítését.

\section{Kulcsszavak: projektmenedzsment, projektportfólió, vezetés, stratégia}

Nem kétséges, hogy az elmúlt évezred végétốl a nagy szervezetekben - legyenek azok vállalatok vagy közintézmények - egyre gyakoribbá vált a projektportfólióban való gondolkodás, valamint a projektek egy adott csoportjának projektprogramként történô teljesítése. Ennek alapvetô okaként Aubry, Hobbs és Thuillier (2007) azt az innovatív törekvést jelölik meg, miszerint a vállalatok folyamatosan igyekeznek a termék- és szolgáltatásportfóliójuk megújításával együtt a piacra jutási időt is csökkenteni. A körülmények így szükségszerúen nemcsak egyszerúen a projektek számának növekedéséhez vezetnek, hanem a projektek egy-egy olyan csoportjának a kialakítását is szükségessé teszik, amelyekben a teljesítésük során egymással szorosan, nemegyszer kölcsönösen összefüggó projektek találhatóak. Az ilyen projektek alkotta programok vezetése - szögezi le Maylor et al. (2006) - túlmutat az egyes projektek vezetésének mesterségén.

Ugyanakkor azt is meg kell jegyezni, hogy az öszszetartozó projektek csoportjának sikeres teljesítése feltételezi a csoportba tartozó egyes projektek sikeres teljesítését is. Mindezzel együtt, ahogy arra Martinsuo és Lehtonen (2007a) is felhívják a figyelmet, a pro- jektek alkotta programok teljesítésének hatékonysága és sikeressége, illetve ezek vizsgálata kevés figyelmet kap a kutatásokban és a publikációkban. A hivatkozott szerzőpáros vizsgálja ugyan ezt a kérdéskört, noha meglehetôsen általános szinten, így fô megállapításuk lényege abban foglalható össze, miszerint a projektprogramok sikerességének legfóbb záloga a programba tartozó projektek hatékony vezetése. Az általuk hivatkozott szerzók többsége is - így például Artto és Dietrich (2004), Dietrich és Lehtonen (2005), Elonen és Artto (2003) vagy Payne és Turner (1999) - úgymond csak annyit állít, hogy az egyedi projektek sikerességét elősegítő tényezók (mint például a világos célmeghatározás, a szisztematikus döntéshozatal, a felsővezetốk támogatása stb.) minden bizonnyal hozzájárulnak a projektprogramok sikerességéhez is. Az egyes projektek sikeressége is nyilvánvalóan több tényező eredményeként jöhet csak létre, nem beszélve akkor a projektprogramok vitathatatlanul összetettebb jellegéból adódó körülményekról.

A projektprogramok teljesítésével foglalkozó, a cikkben hivatkozott szakirodalmi források többsége, alapvetően egyfajta általános közelítésmódjuk követ- 
keztében elsôsorban a programiroda szükségességét és szerepét hangsúlyozzák, mint a programok teljesítésének meghatározó feltételét. Ez - mint a késóbbiekben látni fogjuk - kétségkívül szükséges, de egyben nem az elégséges feltétele is a projektprogramok hatékony teljesítésének.

A szakirodalom ugyanakkor nem számol be olyan, empirikus kutatási eredményeken alapuló adatokról eltérően az egyedi projektekre vonatkozó hasonló adatoktól -, amelyek felfednék a projektprogramok sikerességének vagy sikertelenségének mértékét, vagy azok arányát egy vizsgált halmazon belül. Ezzel kapcsolatban Thiry és Deguire (2007) joggal hívják fel a figyelmet arra a jelenségre, miszerint jelenleg nincs szakmai közmegegyezés annak módjáról, ahogyan az egyedi projektek vezetésére vonatkozó tudás átvihető és alkalmazható a projektprogramok sikeres vezetésében.

Egy, az elmúlt év elején megkezdett kutatás éppen ezért arra vállalkozott, hogy feltárja az egyedi projektek vezetésében alkalmazott projektvezetési eszközök alkalmazási lehetóségeit a projektprogramok sikeresebb teljesítése érdekében. A kutatás kiinduló feltevései a következő́k voltak:

- A projektprogramok projektekból állnak, de ezeket a projekteket nem egyenként - egymástól függetlenül -, hanem programként teljesítik, minthogy a programok projektjei egymással szorosan és többnyire kölcsönösen összefüggnek.

- A projektprogramok teljesítésének vezetése nem azonos, sốt több, mint egy nagyméretú és komplex, de más projekttől függetlenül is teljesíthetô projekt vezetése.

- Egy projektprogram projektjeit az alapul szolgáló szervezeti stratégián kívül még más összekötő kapocs is egybefúzi és kölcsönös összefüggésben tartja, így a projektportfólió fogalma nem szükségszerúen azonos a projektprogram fogalmával.

- Az egyedi projektvezetési eszközök programszintú alkalmazási lehetôségei (az egyedi projektek vezetésére vonatkozó tudás átvitele) a program projektjeit - az alapul szolgáló stratégiai célon túli - összetartó kapcsok mibenlétében keresendôk.

A kutatás célja tehát nem veti el Martinsuo és Lehtonen (2007a) már hivatkozott megállapítását, miszerint a projektprogramok teljesítésének hatékonyságát a benne lévő projektek vezetésének megfelelősége biztosítja. Ugyanakkor ennél az általános megállapításnál tovább kívánt lépni az elóbbi feltevések alapján. Minthogy az ördög a részletekben van, így a kutatás során arra kerestem a választ, hogy az egyedi projektek szintjén alkalmazott projektvezetési eszközök hogyan tehetők alkalmassá a projektprogramok hatékony vezetésére.

A kutatási cél eléréséhez olyan kvalitatív kutatási módszert alkalmaztunk, amely alapvetően esetelemzést és kiegészítésként, az esetelemezésekból származó információk és megállapítások pontosítására, mélyinterjúk készítését foglalta magában. A választott kutatási módszer megfelelôségét gyakorlatilag is alátámasztja az a körülmény, hogy hasonló kvalitatív módszert más konkrét céllal sikeresen alkalmazott Morris és Jamieson (2005), valamint Blomquist és Müller (2006) a projektportfóliókra és projektprogramokra vonatkozó kutatásuk során.

A kutatási célkitúzés megvalósítása szükségessé teszi a projektprogramok teljesítésében tetten érthetô fóbb problématerületek feltárást. A kutatás kiindulópontjait képező feltevések pedig indokolttá teszik, hogy a kutatási eredmények bemutatása előtt áttekintsük a projektportfóliók és a projektprogramok helyét és szerepét a szervezetekben, valamint értelmezzük a két fogalom tartalmi különbségeit.

\section{Projektportfólió - projektprogram}

Jóllehet sem a projektportfólió, sem a projektprogram nem tekinthetố új keletú jelenségnek a gyakorló szakemberek és a kutatók körében, mégis sokszor bizonytalanság veszi körül azok fogalmi meghatározását.

Gareis (2004) közelítésmódja szerint a projektprogram lényege, hogy az egy ideiglenes szervezet, de szemben a projekt fogalmával (ami szerinte szintén egy ideiglenes szervezet), nem egyszerúen csak egy egyedi feladatra létrehozott, hanem egyben egy nagy komplexitású feladatra létrehozott szervezet. Morris és Jamieson (2005) átfogó áttekintést adnak a megelőzố publikációk alapján a kérdéskört kutató elméleti szakemberek projektre, projektprogramra és projektportfólióra vonatkozó meghatározásairól. Maguk a szerzók nem fogalmaznak meg új definíciókat, de fontosnak tartják kiemelten hangsúlyozni, hogy mind a projekteknek, mind pedig a projektprogramoknak és projektportfólióknak meghatározó szerepük van a szervezeti stratégiában, illetve annak teljesítésében.

Blomquist és Müller (2006), hivatkozva Cooper, Edgett és Kleinschmidt (2000) tanulmányára, kiemelik, hogy a projektportfólió kezelése a vezetối döntéshozatal olyan kerete, amelynek fókuszában a stratégiai célok elérése szempontjából megfelelő projektek kiválasztása áll, míg a projektvezetés arra irányul, hogy a projekteket megfelelóen teljesítsék. Egyben hangsúlyozzák, hogy a projektportfólió-kezelés a szervezet eróforrásai 
révén összekapcsolt projektek kiválasztásának és rangsorolásának vezetói módszere. A projektprogramok, és azok vezetése kapcsán a szerzópáros megállapítja, hogy azok különböznek a projektportfólióktól, illetve kezelésüktól, miközben azt is kijelentik, hogy a projektprogramok vezetésének elsődleges célja a projektek, és így egy egész projektprogram realizálandó céljainak pontos meghatározása. Figyelemre méltó, miszerint a szerzók a vezetői hierarchiában elfoglalt hely szerinti különbségekre is rámutatnak. Így a projektportfoliók kezelését alapvetően felsővezetôi feladatnak tekintik, míg a projektprogramok vezetése inkább középvezetói vagy az alatti vezetói feladat.

Pellegrinelli et al. (2007) megközelítésében a projektprogramok a tervezett változtatás, vagyis a stratégia megvalósításának eszközei. Ebben a közelítésmódban a programvezetés a projektek egyfajta koordinációs mechanizmusa a program révén elérendô cél érdekében. (Érdekes a szerzók programtipológiája, miszerint a program lehet: portfolió, célvezérelt és heartbeat (szívverés), noha a szerzók nem fejtik ki az egyes típusok mibenlétét).

Martinsuo és Lehtonen (2007a, b) a projektportfólió fogalmát gyakorlatilag azonos értelemben használják a projektprogram fogalmával. Mindenesetre a szerzók, hivatkozva számos, korábban megjelent publikációra, azon az állásponton vannak, miszerint a projektportfólió a projektek olyan csoportjai, amelyek nemcsak egyszerúen azonos eróforrásokat használnak, de egyben versenyben is vannak egymással ezekért az eróforrásokért a szervezet felsôszintú vezetôinek felügyelete mellett. Aubry, Hobbs és Thuillier (2007) mintegy a szervezet egészének szintjére emelt projektvezetésként értelmezik a projektportfólió és a projektprogram kérdéskörét, amelyek célja a szervezeti stratégia megvalósítása.

Thiry (2004) megközelítésében a projektprogram vezetése több, egymással összefüggó projekt vezetését foglalja magában, míg a projektportfólió kezelése ugyanezen szerző szerint (2006) a szervezeti eróforrások értékelése és allokálása projektekre és projektprogramokra annak érdekében, hogy a szervezet elérje céljait és a szervezet érintettjei számára értéket teremtsen. Maylor et al. (2006), hivatkozva Andersen és Jessen (2003) tanulmányára, határozott különbséget tesz a projekt(vezetés), a projektprogram(vezetés) és a projektportfólió(kezelés) között. E szerint az elsô fókuszában az egyedi projektek, a másodiknál a projektek egy olyan csoportja, amely egy közös cél elérésére irányul, míg a harmadik esetében az egyidejúleg teljesített projektek és programok állnak. Ez utóbbiakat azonban nem kapcsolja szükségszerúen egybe egyfajta azonos (stratégiai) cél. Hasonlóan értelmezi a projektportfólió(kezelés) fogalmát Rad és Levin (2006) is, kiemelve annak stratégiaorientált szemléletmódját, aminek révén az a szervezet egészét érinti.

Áttekintve az elmúlt néhány év publikációiban megfogalmazott fogalmi értelmezéseket, megállapítható - eltekintve néhány markánsan különbözô megközelítéstôl (pl. Gareis, 2004) -, hogy a szerzók többsége a lényeget tekintve azonosan értelmezi a projektportfólió(kezelés) és a projektprogram(vezetés) fogalmait. E szerint a projektportfólió a szervezet egészét érintố stratégiai kérdés, amely magában foglalja mindazokat a projekteket, amelyek az aktuális szervezeti stratégiai célrendszer elérését segítik elô. Ebben az értelemben a projektportfólió a tudatosan kialakított szervezeti stratégia realizálásának eszközrendszere.

Ezzel szemben a projektprogramok (vezetése) a portfólióprojektjeink teljesítésére koncentrál. Ebból azonban még nem következik, hogy egy adott szervezetben a projektprogram tartalmilag azonos a szervezet projektportfóliójával. Fontos ugyanis szem elôtt tartanunk, hogy a projektprogramba tartozó projektek egymással összefüggnek (Thiry, 2004; Morris - Jamieson, 2005). Így fel kell tennünk azt a kérdést, hogy milyen konkrét módon megnyilvánuló projektek közötti összefüggésról van szó egy adott programba tartozó projektek esetében, lévén, hogy ennek konkrétumaira a korábbiakban hivatkozott irodalmakban nem kapunk egyértelmú választ. Amennyiben egy program projektjei révén elérendő azonos stratégiai célt tekintjük a projektek közötti összefüggések alapjának, akkor így nem tudunk különbséget tenni a portfólió projektjei és a program projektjei között. Vagyis így végsô soron egy szervezet projektportfóliója egyetlen projektprogramot alkotna, illetve egy-egy specifikusabb stratégiai cél elérését eredményezó projektek halmaza - függetlenül a közöttük meglévő, vagy éppen hiányzó egyéb összefüggéstől - képezne egy-egy kisebb projektprogramot, amelyek összessége a projektportfólió egészével lenne azonos.

Minthogy a projektportfólió kialakításával szemben a projektprogramok vezetése - a hivatkozott szerzók többsége szerint is - teljesítésorientált közelítésmódot jelent, így célszerúnek túnik egy programot alkotó projektek közötti összefüggés mibenlétét a portfólióba tartozó projektek teljesíthetôségét alapvetôen meghatározó körülményekben keresni. A kutatás során tanulmányozott programok kapcsán két ilyen alapvetô körülményt azonosítottunk:

- ezek egyike a teljesítés azonos (közös) erőforrásszükséglete,

- a másik pedig az elérendô projekteredmények tartalmi kapcsolata.

\section{VEZETÉSTUDOMÁNY}

XXXIX. ÉVF. 2008. 10. SZÁM 
Ennek megfelelóen egy portfólió projektjei között találhatóak olyanok, amelyek a teljesítésük során a többi projekttól eltérố erôforrást igényelnek, vagy olyanok, amelyek esetében a létrehozandó projekteredményt nem befolyásolja a más projektek által létrejövő, részleteiben esetleg még előre nem is látható projekteredmény. Ezek az egyedi projektek. Célszerú azonban azokat a projekteket programként teljesíteni, ahol az említett összefüggések valamelyike (legalább az egyik, de nem kizárt, hogy mindkettố egyidejúleg) fennáll a projektek között a teljesítésük során. Ugyanakkor a portfólióba tartozó többi projekt egymástól függetlenül, egyedi projektként is teljesíthető. Ennek megfelelően egy szervezet projektportfóliója tartalmazhat egyedi projekteket és projektprogramokat egyaránt, miközben a projektportfólió kialakítása alapvetôen a stratégiai vezetés feladata, míg a projektprogramok kialakítása a projektvezetési szint feladata. Éppen ezért nem tekintjük a teljesíthetôség szempontjából figyelembe veendő projektek közötti eróforrás-alapú összefüggésként az idôzítésen és a finanszírozhatóságon (mint két speciális erőforráson) alapuló összefüggést, mert ezek stratégiai, azaz projektportfólió szintú kérdések. Más megközelítésben ez utóbbi azt is jelenti, hogy a projektprogramok kialakításakor a projektportfólió már adott, tehát a stratégiai célok alapján már korábban meghatározott.

\section{A kutatás és a kutatás során a projektprogramok teljesítésében feltárt fóbb problématerületek}

A kutatómunka során, a legfrissebb szakirodalmi források áttanulmányozását követôen, egy háromlépcsôs megközelítést tartalmazó kvalitatív módszert alkalmaztunk. Az elsố lépésben egy feltáró jellegú, ennek megfelelően csak a vizsgált projektprogramot meghatározó sajátosságok áttekintését biztosító mélyinterjúra került sor hat program vezetésében kulcsszerepet játszó vezetókkel. Ennek eredményeként megállapítást nyert, hogy a hat program közül három esetében nem áll fenn a programba tartozó projektek között sem a közös (azonos) erőforráson alapuló, sem pedig a létrehozandó projekteredmények tartalmi kapcsolódásán alapuló összefüggés. Valójában ebben a három esetben a projekttulajdonosi szervezetben a programba tartozó projektek kiemelt stratégiai fontossága miatt kezelték azokat úgymond programként, noha a projektek valójában egyedi projektként teljesíthetóek voltak. Így a további kutatómunkában már ezt a három programot figyelmen kívül hagytuk.

A további három projektprogram kapcsán mélyebb esetelemzésre került sor, amelynek során a rendelkezésre álló információk alapján áttekintettük és elemeztük:
- a program szervezeti kereteit (tekintet nélkül az egyes projektekben alkalmazott szervezeti megoldásra),

- a programba tartozó projektek tartalmi, terjedelmi behatárolását,

- a program és projektjeinek teljesítési terveit, és

- a teljesítés során alkalmazott kontroll kérdésköreit, nemcsak a programba tartozó egyes projektek, hanem programszinten egyaránt.

A dokumentumokból nyerhetố információk kiegészítésére és pontosítására mélyinterjúk formájában került sor a program és a programba tartozó projektekben kulcsszerepet betöltô vezetôkkel. Az így vizsgált projektprogramok egyike egy fuvarozóvállalat programja volt, amely a vállalat piacbóvítési stratégiai célját volt hivatva megvalósítani. Ennek elérésére fogalmazódott meg a vállalat képességeit bővítő program, amelynek eredményeként a vállalat egyszerú fuvarozóból olyan szállítmányozóvállalattá válhat, amely egyaránt képes vasúti, szárazföldi és vízi úton történő fuvarszervezésre. A program a következô projekteket foglalta magában:

- a szállítmányozási múködési folyamat, az ehhez szükséges szervezeti kapacitás és infrastruktúra kialakítása, valamint a múködést segítő technikai infrastruktúra kialakítása,

- stratégiai partnerség létrehozása alternatív fuvarozási kapacitással rendelkező fuvarozóvállalatokkal,

- logisztikai bázis kialakítása.

Könnyen belátható, hogy a programba tartozó projektek között alapvetôen az egyes projekteredmények tartalmi kapcsolatán alapuló összefüggés a domináns. A teljesség igénye nélkül, csak példaként említve azt, hogy az elsóként említett projekt tartalmát befolyásolja a stratégiai partnerek meglévő képessége, de ugyanígy a kialakítandó logisztikai bázis földrajzi helyszíne és egyéb adottságai is.

A másik programnak otthont adó szervezet egy egészségügyi intézmény, ahol a szervezeti stratégia alapvetô célkitúzése a hatékonyság növelése a meglévố kapacitások jobb kihasználásával. Ez a program az alábbi projekteket fogja össze:

- a kutatási tevékenység szélesítése új, a készségfejlesztésében eddig nem kutatott területen,

- speciális, gyakorlatilag hiánypótló egyetemi alapképzési program kialakítása és a képzés elindítása,

- új, eddig nem alkalmazott készségfejlesztő programok alkalmazásba vétele.

A programra vonatkozó információk egyértelmúvé tették, hogy a három projekt között mind az erőforrás- 
alapú, mind az egyes projekteredmények tartalmi kapcsolatain alapuló összefüggés jelen van. Mindhárom projekt esetében jelentôs átfedés található a teljesítéshez szükséges szakemberállományban, ugyanakkor belátható, hogy például a képzési program tartalmát részben befolyásolja mind az elsóként, mind az utolsóként említett projekt, lévén, hogy teljes mértékben speciális profilú egészségügyi intézményrôl és ugyanilyen jellegú képzési programról van szó.

A harmadik, részletesebben vizsgált program egy építőipari tervezéssel és kivitelezéssel foglalkozó, tehát projektalapú vállalkozás egyik programja. Egyrészt a vállalat ágazati hovatartozásából, másrészt projektalapú jellege révén ebben az esetben a programképzés elsôdleges szempontja a földrajzi régió volt, az eróforrások minél hatékonyabb kihasználása a profitnövelés, mint stratégiai cél elérése érdekében. Így egy adott program fogta össze azokat a kivitelezési projekteket, amelyeket egy kisebb régióban, tehát földrajzilag közel egymáshoz teljesítettek. Szinte magától értetődő ebben az esetben, hogy egy adott program projektjei közötti összefüggés eróforrás-alapú. Az egyes kivitelezési projektek ugyanazokat az (ugyanolyan) emberi és gépi eróforrásokat igénylik.

A korábbiakban definiált értékelési szempontok alapján a vizsgált programokkal kapcsolatban az alábbi megállapítások tehetók:

- Ami a programok szervezeti kereteit illeti, a fuvarozóvállalat esetében létrehoztak egy programirodát, amely alapvetóen a szakirodalomból (pl. Letavec, 2006; Hobbs - Aubry, 2007; Aubry - Hobbs - Thuillier, 2007 stb.) ismert feladatokat igyekezett ellátni. Ugyanakkor sem az egészségügyi intézményben, sem az építőipari vállalatnál nem volt programiroda. Az egészségügyi intézmény esetében az elsô számú vezető látta el egyben a programvezetói feladatokat is, míg az építóipari vállalatnál a vállalkozási igazgató felügyelte a programok teljesítését. Mindhárom programban voltak projektvezetők (ezt a pozíciót az építóipari vállalatnál építésvezetőnek nevezték), de pozíciójuk legerősebb a fuvarozóvállalatnál, míg a leggyengébb projektvezetối pozíció az egészségügyi intézmény programjában volt tetten érhetô.

- A projektbehatárolás lényegében mindhárom program projektjeiben megtörtént, de jellemzóen az egyes projektek szintjén és a programba tartozó projektektól elvárt eredmények behatárolásának összességét tekintették a program tartalmiterjedelmi határainak.
- A program teljesítési tervei mindhárom program esetében elsősorban a projektek időtervét és költségtervét jelentették, de nem elhanyagolható különbség volt a tervek színvonalában és tartalmában a három program között. Az egészségügyi intézmény programja és projektjei gyakorlatilag nem rendelkeztek a szó valódi értelmében vett költségtervvel, de a program teljesítésében résztvevốk számára ismert volt az egyes projektekben teljesítendő feladatuk. Ugyanakkor az építőipari vállalat programjában az egyes projektekre vonatkozóan eróforrásterv is készült.

- A teljesítésre vonatkozó kontrollról elmondható, hogy eredménykontrollra egyik esetben sem került sor, míg a folyamatkontroll alkalmazása igen eltérő képet mutatott mindhárom program esetében. Az egészségügyi intézményben csak szöveges értékelés történt a programba tartozó egyes projektek előrehaladásáról, a fuvarozóvállalat programjában lényegében az EVA alapján történt az egyes projektek teljesítési állapotának értékelése, míg az építőipari vállalat programjában - szintén csak az egyes projektek szintjén - nyomon követték a költségek alakulását és a teljesítés előrehaladását, noha ez utóbbit naturális adatok alapján.

A továbbiakban, mellózve a tapasztalt jelenségek technikai jellegú részleteit, áttekintjük a vizsgált programok teljesítésében azonosított főbb problématerületeket:

- A programok teljesítése során meghozandó döntések elhúzódása hátráltatta az egyes projektek előrehaladását. Ez különösen jellemzô volt az egészségügyi intézmény programja esetében, aminek oka a már említett szervezeti keret ottani sajátos megoldásában keresendő.

- A program egyik projektje elérendô eredményében bekövetkező változásnak a program más projektjeire gyakorolt hatását nem, vagy nem maradéktalanul vették figyelembe. Ez a jelenség leginkább a fuvarozóvállalat programjában volt tetten érhetố, elsố számú okként pedig az eredménykontroll hiányában jelölhetô meg.

- A program egyik projektjében az időtervtól eltérô teljesítésnek a program más projektjeinek teljesítésére gyakorolt hatását nem kielégítóen kezelték, ami többnyire az építôipari vállalat programja kapcsán volt érzékelhetô, veszélyeztetve így a programba tartozó projektek határidőre történó teljesítését. A jelenség oka leginkább a sziszte- 
matikus, a naturálisan különböző tevékenységekben elért teljesítések összehasonlítását lehetôvé tevő folyamatkontroll hiánya.

- A program projektjeinek határai - a létrehozandó projekteredmény tartalmi-terjedelmi keretei - nem minden esetben voltak egyértelmúek és világosak, így előfordult, hogy bizonyos, a program egészének teljesítése és céljának elérése érdekében szükséges tevékenységek figyelembevételére egyik projektben sem került sor, aminek következtében sem eróforrást, sem idôtartamot, sem költséget nem terveztek be az ilyen tevékenységek kapcsán. Ez a probléma elsôsorban a fuvarozási vállalat és az egészségügyi intézmény programjainál fordult eló.

- A vállalat stratégiájában a programok teljesítése közben bekövetkezô változás programra gyakorolt, és ezen keresztül a program projektjeire gyakorolt hatását, sokszor nem, vagy nem megfelelően vették figyelembe, és nem érvényesítették. Ez a körülmény leginkább a fuvarozóvállalat programját érintette.

A két, utóbbi fó problématerület kapcsán az érintett szervezetekben nemcsak a vonatkozó eszköztár ismeretének a hiánya, hanem a stratégiaorientált szemléletmód hiánya is említést érdemel.

Természetesen a fentieken túl bizonyára további problématerületek is megfogalmazhatók a programok teljesítéséról, noha a korábban megfogalmazott kutatási célok szempontjából ezek a problématerületek a döntő mértékben meghatározóak. Természetes, hogy más szerzốk más kutatási célkitűzés alapján, más problématerületeket fogalmaznak meg. Így például Blomquist és Müller (2006) a középvezetók szerepe szempontjából közelíti a projektportfóliók és a projektprogramok vezetésének kérdéskörét, így nyilvánvaló, hogy az ebben rejlő problémákat helyezik előtérbe. Pellegrinelli et al. (2007) pedig a program szervezeti környezetének sajátosságait, illetve azok figyelembevételének szükségességét hangsúlyozza a programok teljesítése során.

Martinsuo és Lehtonen (2007a) vizsgálják ugyan az egyes projektek szerepét a projektportfóliók és projektprogramok hatékony teljesítésében, de - ahogy erre már korábban is történt utalás - nem specifikusan az egyedi projektvezetési eszközök szempontjából, így megállapításaikat is egy általános szinten értelmezve fogalmazzák meg. Ugyanakkor ók is rámutatnak - többek között - a programba tartozó projektek tartalmi-terjedelmi behatárolásának hiányosságaiból fakadó problémákra.

\section{Az egyedi projektvezetési eszközök alkalmazhatósága a projektprogramok teljesítésében feltárt fóbb problématerületek kiküszöbölésére}

A projektprogramok definíciója kapcsán több szerzô is kiemeli - a leghangsúlyosabban talán Thiry (2004) - a programot alkotó projektek közötti összefüggést mint a program legfontosabb megkülönböztető sajátosságát, noha specifikusan nem fogalmazza meg az összefüggés mibenlétét. E tanulmány egy korábbi pontja pedig megfogalmazta azt, hogy ez az összefüggés tartalmilag lehet egyrészt erőforrás-alapú, amikor a program projektjei közötti összekötő kapocs az azonos eróforrás-szükséglet; másrészt lehet az összefüggés a programba tartozó projektek elérendô eredményeinek tartalmi kapcsolatán alapuló. Ez a felismerés nemcsak az elméleti tisztánlátás érdekében szükséges, hanem segítségünkre van annak felfedésében is, hogy a feltárt fóbb problématerületek miként küszöbölhetốk ki, vagy legalábbis miként minimalizálható a potenciális kedvezőtlen hatásuk az egyedi projektvezetési eszközök programszintú alkalmazásával. Vegyük tehát sorra újra ezeket a fóbb problématerületeket. Észrevehetô, hogy ezek a problématerületek a következố projekt- és programvezetési problémákként is értelmezhetôk:

- döntéshozatali problémák,

- koordinációs problémák,

- behatárolással és változáskezeléssel összefüggő problémák,

- projektkontrollal összefüggó problémák,

- a teljesítési tervek (idő-, erőforrás- és költségterv) készítésével összefüggő problémák.

Nézzük meg először azt, hogy az egyedi projektekben milyen projektvezetési eszközökkel kezelhetók ezek az egyébként az egyedi projektek szintjén is gyakran megjelenő, sokszor egymással kölcsönösen összefüggó problémák.

A döntéshozatali és a koordinációs problémák kezelésének alapvető eszközei az egyes projektszervezeti megoldások, amelyek egyébként jól ismertek a projektvezetés alapmúveinek számító könyvekboól. A koordináció eszközének tekinthetóek ugyanakkor - mint egyfajta standardizálási eszközrendszer - a projektteljesítési tervek is. A döntéshozatali problémák kezelésében kiemelkedô szerepe van továbbá a projektkontrollnak - ami lehet eredménykontroll vagy folyamatkontroll - lévén, hogy a projektkontroll a lényegét tekintve a projektért felelósséggel tartozó vezetók számára kialakított döntéstámogató információs rendszer. 
A projektbehatárolással és a változáskezeléssel öszszefüggố problémák megoldásának alapvetố eszközei a szakirodalomból kevéssé ismert struktúratervek, úgymint a stratégiaorientált projektbehatárolást segító funkció-cél struktúra, amely a létrehozandó projekteredmény elvárt (funkcionális és nem funkcionális) képességeit tárja fel; továbbá az eszközstruktúra, amely az elvárt képességek realizálását lehetôvé tevő eszközrendszert (pl. technikai megoldási lehetôségek, a projekteredmény részévé váló eszközök stb.) öleli fel (Görög, 2000, 2003; Andersen - Grude - Haug, 2004). Noha elengedhetetlen a tartalmi-terjedelmi behatárolás során is, de a változáskezelés kapcsán még inkább létfontosságúvá válhat a stratégiaorientált projektvezetési szemléletmód, annak érdekében, hogy a létrehozandó projekteredmény mindvégig összhangban legyen, illetve maradjon a létalapjául szolgáló stratégiai céllal. Valójában erre a szemléletmódra épül az elóbb említett stratégiaorientált projektbehatárolás is. A változáskezeléssel összefüggó problémák megoldásában és az erre vonatkozó döntéshozatalban ugyancsak segít a teljesítés során alkalmazott eredménykontroll.

A projektkontrollal kapcsolatos problémák megoldására a szisztematikus, vagyis a jellegében különbözô projekttevékenységek készültségi állapotának öszszemérését lehetôvé tevő folyamatkontroll (pl. EVA), illetve a projektbehatárolás során megfogalmazott, önmagában is mérhetô részeredmények mérföldkövenkénti értékelése - az eredménykontroll - biztosít lehetôséget. A teljesítési tervek alfája és omegája az erôforrás-allokáció, minthogy az idôtartam, túl a projektfeladatban foglalt munkaterjedelmen, lényegében a felhasznált eróforrások mennyiségétől és teljesítóképességétól függ, miközben a teljesítés költségei egyrészt az erôforrások lekötésének idôtartamával, másrészt pedig a használatukkal arányosan merülnek fel. Az egy másik kérdés, hogy általában az idő, az erôforrás és a költség mértéke között szoros és kölcsönös összefüggés áll fenn. Az egyedi projektek szintjén az erőforrás-allokáció alapvetố eszköze a feladat-felelósség mátrix, amennyiben csak emberi eróforrásról van szó, illetve a tevékenységek-eróforrás mátrix, amenynyiben egy projekt nem csak emberi erőforrást igényel a teljesítése során.

Teljes mértékben elfogadva Martinsuo és Lehtonen (2007a) megállapítását, miszerint a projektportfóliók (programok) teljesítésének hatékonyságában a leginkább döntố tényezó az egyes, a programba tartozó projektek vezetésének hatékonysága, egyidejúleg arra is rá kell mutatni - összhangban a már eddig is idézett szerzók többségével - hogy egy projektprogram több, mint a programot alkotó projektek összessége.
A programot alkotó projektek közötti összefüggések - a program projektjeit összekötő kapcsok - új minőséget és egy magasabb komplexitást hoznak létre egy projektprogram számára, mint amit néhány egyedi projekt alkotta halmaz jelenthet.

Ebból a körülményból kiindulva pedig az következik, hogy az egyedi projektekben alkalmazott projektvezetési eszközöket most a program szintjére értelmezve is tudni kell alkalmazni. A kutatás során azonosított problémák kezelésére az előzőekben megfogalmazottak szerint az egyedi projektekben a következó projektvezetési eszközök lehetnek a segítségünkre:

- projektszervezeti megoldások (döntéshozatal, koordináció),

- projektteljesítési tervek, kiemelten pedig a feladat-felelősség mátrix (koordináció, erőforrás-allokáció),

- projektkontroll, vagyis eredmény- és folyamatkontroll (döntéshozatal, változáskezelés, a teljesítés nyomon követése),

- struktúratervek, vagyis a funkció-cél struktúra és az eszközstruktúra (projektbehatárolás, változáskezelés).

Egy projektprogram esetében a szervezeti megoldást az erre a célra kialakított programiroda jelenti. Ebben gyakorlatilag a témakörrel foglalkozó szerzók mindegyike egyetért, sốt Gareis (2004) magát a projektprogramot is elsősorban egy ideiglenes szervezetként határozza meg. A programiroda kérdéskörét az utóbbi években számos kutató vizsgálta, csak a legutóbbi néhány évben is több, ezzel kapcsolatos publikáció látott napvilágot. Ezek egyike (Hobbs - Aubry, 2007) átfogó áttekintést ad a korábbi évek témáival kapcsolatos publikációiról, miközben a szerző́k nyomatékosan felhívják a figyelmet arra, hogy kerüljük a programiroda nem megalapozott (naiv) elvárások és feltevések alapján történő létrehozását és múködtetését. Aubry, Hobbs és Thuillier (2007) ugyancsak áttekintik a korábbi évek publikációiban a projektirodával kapcsolatos közelítésmódokat, miközben a szerzók a programiroda (projektiroda) olyan szemléletmód alapján történô vizsgálatát javasolják, amely támaszkodik a különféle szervezetelméleti közelítésmódokra és innovatív teóriákra. Thiry és Deguire (2007) a programirodák szerepét vizsgálva megfogalmazzák az azokkal szembeni, legfontosabbnak tartott elvárásaikat, kiindulva abból, hogy a projektprogramok szerepe a szervezeti stratégia céljainak elérése. Ennek megfelelöen egy programirodának képesnek kell lennie arra, hogy megküzdjön az előre nem látható helyzetekkel, amiből az következik, hogy a programiroda vezetőjének nagyfokú önállósággal kell rendelkeznie. 
Elfogadva Letavec (2006) álláspontját, a programiroda alapvető feladatait a következókben határozhatjuk meg:

- tanácsadói feladatok, amelyek keretében segít a programba tartozó projektek vezetóinek a megfelelő projektvezetési eszközök megfelelő alkalmazásában,

- tudáskezelői feladatok, amelyek keretében a felhalmozott (tapasztalati) tudást általánosítják a program projektjei között,

- standardizáló feladatok, amelyek keretében a projektvezetési feladatokat (tervezés, kontroll stb.) azonos elveken nyugvó folyamatokban alakítják ki, és teljesítik azokat a program egészében.

Amelyik programiroda betölti a fentiekben megfogalmazott feladatait, úgy megfelelő szervezeti keretet biztosít a kutatás során feltárt problématerületek kiküszöböléséhez (döntéshozatal, koordináció), mintegy ernyôként átfogja a megoldásként említett projektve- zetési eszközök projektprogramszintú alkalmazását. Itt célszerú ismételten hangsúlyozni a stratégiaorientált szemléletmód szükségességét, amellyel a program vezetőjének mindenképpen rendelkeznie kell.

A programiroda kapcsán hivatkozott közelmúltbeli publikációk, valamint a szerzóik által áttekintett nagyszámú korábbi publikáció a projektprogramok teljesítése kapcsán jószerével csak a programiroda szükségességét emelik ki. Ennek oka vélhetóleg az egyfajta metaszemléleten alapuló közelítésmód, holott - mint azt már korábban is említettem - az ördög a részletekben van. Az ilyen ördögök egyike a programot alkotó projektek teljesítési terve, kiemelve közülük is az erôforrás-tervezést (ahogy arra már korábban is rámutattunk, az erőforrások mennyisége és teljesítóképessége jelentős hatással van mind az időtartam, mind a költségek alakulására).

Amennyiben egy projektprogram projektjei csak emberi erôforrást igényelnek (pl. az egészségügyi intézmény programja), akkor az erőforrás-allokáció és

A programszintú feladat-felelôsség mátrix sémája

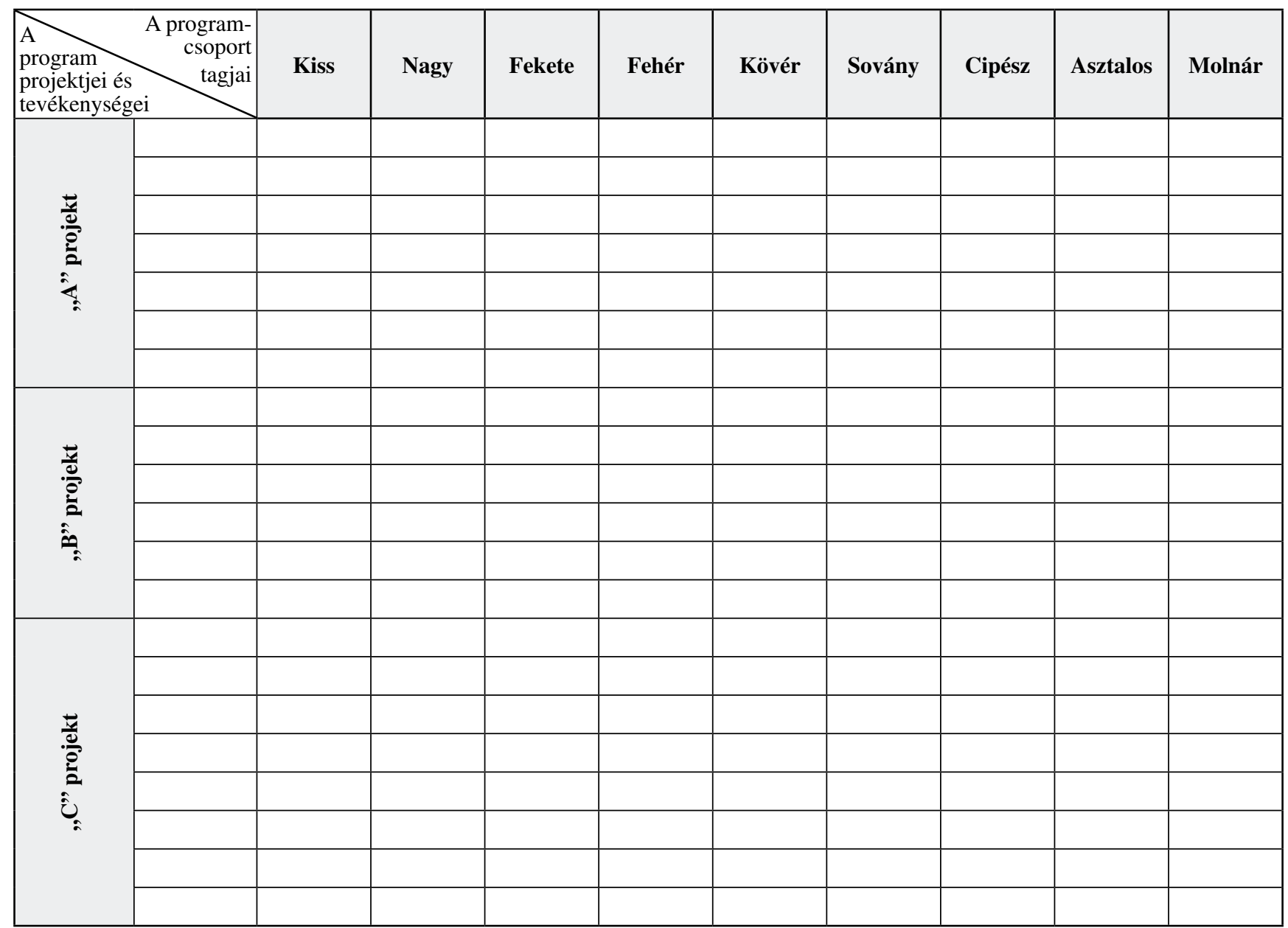


-tervezés alapvető eszköze a feladat-felelősség mátrix. Programról lévén szó, a különbség ezért „csak” anynyi, hogy mindezt most nem egyszerúen a programba tartozó projektekre egyenként kell elkészíteni, hanem együttesen, a program összes projektjét egyszerre tekintetbe véve. Az 1. ábra egy programszintú feladatfelelôsség mátrix sémáját szemlélteti.

Az egyes projekttevékenységek teljesítéséhez szükséges szakmai kompetenciák figyelembevételével minden tevékenység esetében megjelölhetố a megfelelő cellában az azt teljesítő szakember [F] (vagy akár több is), illetve a teljesítést elôsegítő közremúködő [K]. Ezzel együtt az adott cellában (tehát tevékenység/eróforrás alapon) jelölhető a teljesítés idôtartama és a teljesítési idő alatt igényelt munkaterhelés. Mindezen információk birtokában a program egyes projektjei az idó függvényében ütemezhetőek, ami a program projektjeinek idôbeli egymásra épülését (párhuzamosság, átfedés, egymásutániság) eredményezi. Az ütemezés tehát erőforrásalapon történik, vagyis a program projektjeinek időbeli egymásra épülését az egyes projektek azonos erőforrások iránti igénye határozza meg. Turner és Speiser (1992) kidolgozták a projektprogram-teljesítési tervek készítésének információs rendszerét és folyamatát. Az elóbbiekben (1. ábra) bemutatott eszköz nem a szerzók által javasoltakat helyettesító, inkább azokat operacionalizáló eszközként tekintendô. Ugyanakkor a mátrix kialakítása és az arra épülő tervek során célszerú figyelemmel lenni Heumann, Keegan és Turner (2007) azon megjegyzésére, miszerint egy, a programban részt vevô személy nemcsak hogy egyidejúleg a program több projektjében is szerepet játszhat, hanem projektenként eltéró lehet a szerepköre is. Amikor egy projektprogram a teljesítése során az emberi eróforrásokon túl - például a teljesítéshez szükséges gépi erőforrások, illetve a program projektjeinek eredményébe beépülô anyagok és berendezések - egyéb eróforrásokat is igényel, akkor a programszintú tevékenység-erőforrás mátrix kidolgozása válik szükségessé. Ennek elvi felépítése és értelmezése megegyezik a feladat-felelősség mátrixéval, de a három alapvetố eróforráscsoportnak megfelelően három blokkot foglal magában.

Ami a projektkontrollt illeti, ebben a vonatkozásban határozott különbséget kell tenni folyamatkontroll és eredménykontroll között. A folyamatkontroll egyrészt a teljesítés költségeire, másrészt a teljesítés idôbeli alakulásának értékelésére irányul. A projektprogramok teljesítése kapcsán - különösen erőforrásalapon összekapcsolódó projektprogramok esetében - kiemelkedó jelentőséggel bír a teljesítés idóbeli alakulása, hiszen az egyik projektben (vagy annak akár egyetlen tevékenységében) bekövetkezett elmaradás az idôtervtốl akadá- lyozhatja a program többi projektjének időterv szerinti teljesítését. Ugyanígy, a tervhez viszonyított elóbbi teljesítés más projektek elóbbi teljesítéséhez is vezethet. A teljesítésre irányuló, megbízható folyamatkontroll képezi a program teljesítése során a program projektjei közötti vagy egy projekten belüli tevékenységek közötti erőforrás-újraallokálás nemegyszer ismét és ismét felmerülő megoldásának kiindulási alapját. Ennek érdekében elengedhetetlen az olyan folyamatkontroll alkalmazása - amilyen például az EVA (a létrehozott értéken alapuló folyamatkontroll) -, ami lehetővé teszi a naturálisan teljesen különbözố tevékenységekben elért teljesítés egybevetését. A teljesítéskontroll során azonban - éppen a hatékony erőforrás-újraallokáció érdekében - indokolt a részletekbe is betekintést engedő megoldás alkalmazása. Így szükségszerú lehet akár az egyes projekteken belül a tevékenység/idôegység mélységú információgyújtés és értékelés is, amiból a nagyobb aggregáltságú értékelések is kialakíthatóak (pl. tevékenység/eltelt idő vagy összes tevékenység/időegység stb.).

Ami az eredménykontrollt illeti, annak alapjait már a program- és a projektbehatárolások során meg kell teremteni, aminek kiemelkedô fontossága az eredményalapon összekapcsolódó projektek alkotta programokban van. Az elérendő programeredményból levezetett szükséges projekteredmények mindegyike esetében definiálni kell az önmagában is mérhető és értékelhetô eredményrészeket, ami valójában minden egyes ilyen eredményrész adott paraméterek alapján való leírását jelenti. Egy-egy ilyen részeredmény létrejötte egy-egy mérföldkőesemény az időtervben, amelyek egyben az eredménykontroll gyakoriságát is meghatározzák. Egy létrejövő eredményrész aktuális paraméterei egybevethető́k a tervezett és rögzített paraméterekkel, és az esetleges eltérések olyan korrekciót is kiválthatnak, amely a program más projektjeinek eredményeire is hatást gyakorolhat, s ezzel együtt szükségessé tehet erôforrás-újraallokációt és ütemezésre vonatkozó korrekciókat is a program egészében. Ezen a ponton pedig találkozik a folyamatkontroll és az eredménykontroll. Ha mégsem, akkor a program egészének hatékony és sikeres teljesítése válhat kétségessé, de ugyanide vezethet ebben a folyamatban a már említett stratégiaorientált szemlélet hiánya is.

Egy projektprogram elérendő eredményének, és ezen belül az egyes projekteredmények megfogalmazása és behatárolása talán az egyik legnehezebb feladat, noha fontossága elvitathatatlan. Amilyen pontossággal tudjuk ezeket az elérendó eredményeket megfogalmazni, olyan pontossággal tudjuk csak a teljesítési terveket - így az azok alapját képező eróforrásterveket is - elkészíteni. A behatárolás hiányosságai ugyanakkor veszélyeztetik az adott projektprogramot életre hívó 
stratégiai cél elérését is. Elmondható tehát, hogy egy program és projektjei elérendő eredményének pontos behatárolása kétszeresen is indokolt. Ellenkezô esetben egyrészt kétségessé válik a szervezeti stratégia megvalósíthatósága, másrészt megalapozatlanná válik a teljesítési tervek kialakítása, ami önmagában is csökkentheti az alapul szolgáló stratégia realizálhatóságának esélyét. Thiry (2004) fontosnak tartja ebben a folyamatban a kevéssé formalizált és kognitív jelleget. Nem vitatva az említett jelleg fontosságát, annyit min- tek esetében a következő kérdésre keresi a választ: milyen képességekkel (funkcionális és nem funkcionális képességek) kell rendelkezni a létrehozandó projekteredménynek ahhoz, hogy elérhetóvé tegye az alapjául szolgáló stratégiai célt? Ugyanezt a kérdést kell most is feltennünk, de nem egy egyedi projekt kapcsán, hanem egy projektprogram kapcsán. A kérdésre a választ az úgynevezett funkció-cél struktúra (Görög, 1996, 1999, 2000) alapján kaphatjuk meg, amit a 2. ábra szemléltet a fuvarozóvállalat programja alapján.

2. ábra

\section{Programszintú funkció-cél struktúra}

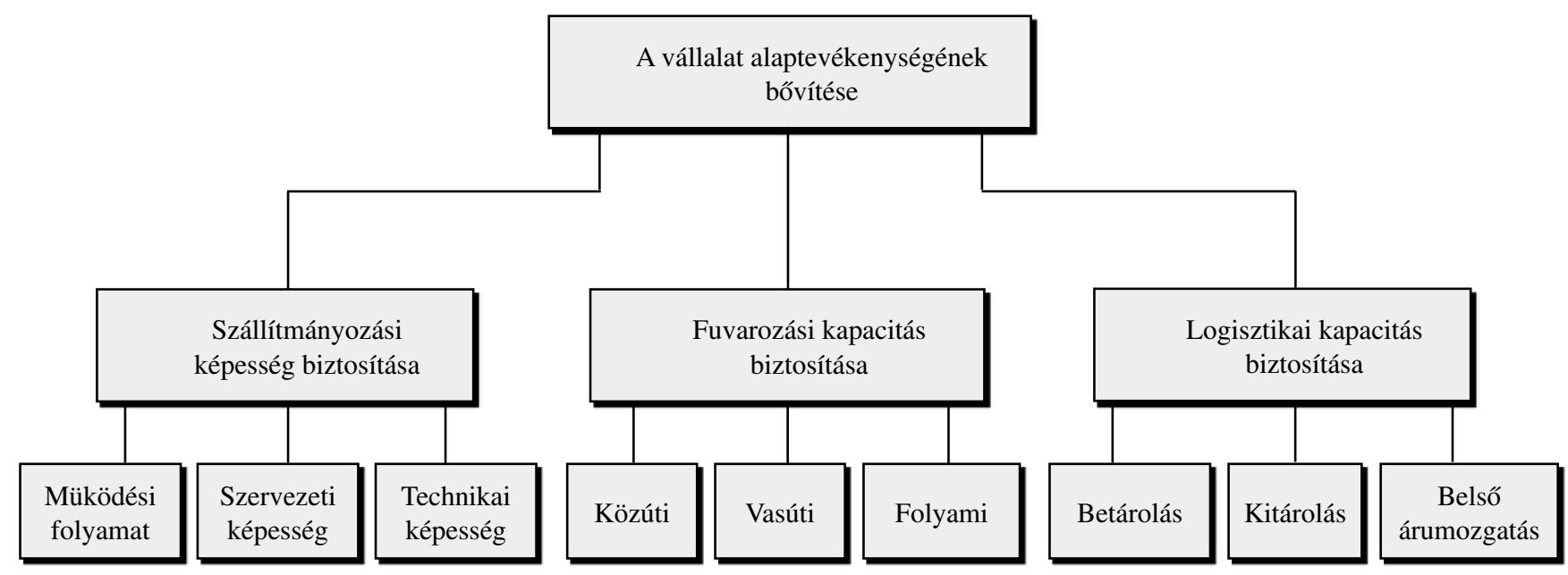

denképpen meg kell jegyezni, hogy jelenlétének indokolt mértéke erôsen függ a kiindulási alapot képező stratégia kidolgozottságának mértékétól. Ha ez a stratégia kevésbé kidolgozott (pl. egy úgynevezett adott helyzetben alakuló stratégia esetében), akkor még a projektprogramok szintjén is indokolt egy kevésbé formalizált, kognitív jellegú folyamat követése. Ugyanakkor, ha a stratégia tudatosan elvégzett elemzési és tervezési folyamat eredménye, ami egyben meghatározza a célok eléréséhez vezetô projektportfóliót is, akkor a projektprogramok kialakítása maga is egy, úgymond ,merevebb folyamat eredményeként valósul meg.

Bárhogyan is fogalmazzuk meg a követendő szervezeti stratégiát, előbb vagy utóbb választ kell adni arra a kérdésre, hogy mik azok a projekt(eredmény)ek vagy a projektek egy-egy csoportját magában foglaló program(eredmény)ek, amelyek teljesítése, illetve megvalósítása szükséges a stratégiai célok eléréséhez. Ez a követelmény vezetett el az úgynevezett stratégiaorientált projektbehatárolás szükségességéhez (Görög, 1996, 1999, 2000) már az egyedi projektek esetében is, és ez a projektbehatárolási közelítésmód alkalmazható a projektprogramok elérendő eredményeinek megfogalmazása során is. Ez a közelítésmód egyedi projek-
Megjegyzendő, hogy a 2. ábra az áttekinthetőség érdekében csak az alapvetô funkcionális képességeket tartalmazza egy nem túl részletes felbontásban, inkább csak illusztrációs jelleggel.

A program elvárt képességeinek ilyen módon történő feltárása lehetôvé teszi, hogy az egyes képességekhez minőségi követelményeket és méretjellemzốket (kapacitás) rendeljünk, ami többnyire csak az itt láthatónál részletesebb felbontás alapján lehetséges. Ha pedig mindehhez az elvárt programeredmény majdani múködési környezetének a sajátosságait is figyelembe vesszük, akkor - egy formailag hasonló ábrázolásban - meghatározhatjuk azt az eszközstruktúrát, amely a szükséges képességeket az adott minőség és kapacitás, illetve múködési környezeti sajátosságok mellett biztosíthat.

A programszinten értelmezett funkció-cél struktúra, valamint az ennek megfelelő eszközstruktúra lehetővé teszi egyrészt a program életképességének az értékelését, másrészt pedig elôsegíti a programon belüli projektek tartalmi határainak a kialakítását, továbbá a teljesítéshez szükséges tevékenységstruktúra (ami a teljesítési tervek kiindulási pontja) meghatározását, és nem utolsósorban az eredménykontrollban szükséges eredményrészek definiálását a vonatkozó paraméterek megadásával. 
A kutatás során a projektprogramok teljesítésében feltárt problématerületek kiküszöböléséhez javasolt egyedi projektvezetési eszközök programszintû alkalmazásának rövid áttekintése is alkalmas arra, hogy észrevegyük a javasolt eszközök alkalmazása közötti, sokszor kölcsönös, összefüggéseket. Így például a programbehatárolás teremti meg az alapot a kontroll és a teljesítési tervek számára, miközben a teljesítés során a kontroll eredményei hatást gyakorolhatnak mind a teljesítési tervekre (pl. eróforrás-újraallokáció), mind az elérendő eredményre (változáskezelés).

\section{Összegzés}

A kutatás fố céljának eléréséhez elengedhetetlen volt feltárni a projektprogramok teljesítése során tipikusnak nevezhető legfontosabb problématerületeket. Ebben a munkában az alkalmazott kvalitatív kutatási módszer alkalmasnak bizonyult, noha kétségtelen, hogy a három, részletesebben elemzett projektprogram kisméretú mintát jelent ahhoz, hogy teljes körben érvényesen általánosítható konklúziókhoz vezessen a feltárt problématerületek itt leírt módon történô kiküszöbölésére, ami a kutatás fớ célkitúzése volt. A vizsgált mintában kifejezett szándékkal kapott helyet egy projektalapú vállalat (az építóipari vállalat), noha az ilyen vállalatok esete talán a projektportfóliók elméleti-módszertani nézôpontjából (pl. a projektek rangsorolása) is vizsgálható. Így ezek a vállalatok célszerúen tudják alkalmazni Gareis (2004) projektportfólió rangsoroló tábláját. Ugyanakkor a kutatási eredmények is megerősítették, hogy sok vonatkozásban (pl. folyamatkontroll, eróforrás-allokáció és -koordináció) más szervezetekhez hasonlóan a projektalapú vállalatok is ugyanazokkal a problémákkal küszködnek a projektprogramok teljesítése során.

Egyetértve ugyan Thiry és Deguire (2007) intelmével, miszerint a projektprogramok vezetése nem azonos a programszintre emelt projektvezetéssel, mégis meg kell jegyezni, hogy a programok ugyanakkor projekteket foglalnak magukban, $\mathrm{s}$ a program egészének sikerességét a benne foglalt projektek vezetésének minősége is befolyásolja (Martinsuo - Lehtonen, 2007a). Ezért indokoltnak látszott vizsgálni azt a kérdést, hogy az egyedi projektek vezetésében alkalmazott eszközök miként alkalmazhatóak a projektprogramok - nem pedig a bennük foglalt egyes projektek - szintjén a fóbb problématerületek kiküszöbölésére vagy megjelenésük mérséklésére.

Ez utóbbi cél érdekében lényeges volt annak megvilágítása, hogy egy program projektjeit - a közös stratégiai célon túlmenóen - milyen további kapocs tartja egyben egy adott projektprogramként. Ennek alapján az mindenképpen megállapítható, hogy olyan projekt- programok esetében, ahol a projektek közötti további összekötő kapocs eróforrás-alapú, ott kiemelkedő fontosságúvá válik a programszintú erôforrás-allokáció, és az ez alapján végzett ütemezés. Azokban a programokban pedig, amelyekben ez a további, projektek közötti összekötố kapocs a létrehozandó eredmények tartalmi összefüggésén alapul, ott létfontosságúvá válik a létrehozandó programeredmény (és ezzel együtt a beletartozó projekteredmények) stratégiai szemléletú behatárolásának kérdése. Természetesen, a kontroll és a szervezeti keret egyaránt fontos minden projektprogramban - bármelyik, a közös stratégiai célon túlmutató kapocs fúzi is egyetlen programmá a projektek egy adott halmazát - éppen a közös stratégiai cél elérése érdekében. Mind a szervezeti keret (a programiroda), mind a kontroll mintegy átívelik a projektprogramok teljesítési folyamatát.

A kutatás alapvetően az egyedi projektvezetési eszközök program szintú alkalmazási lehetôségeit célozta, de a projektprogramok sikeres teljesítésében döntő szerepe van a program- és a projektvezetók stratégiaorientált szemléletmódjának is.

A három programból álló minta valóban kevés, de a speciális, az idézett szerzóktôl eltéró szempontú kutatás eredményei további adalékul szolgálhatnak a projektprogramok mibenlétének jobb megértéséhez és teljesítésük hatékonyságának növeléséhez. Ugyanakkor egy lehetséges módját mutatja ez a tanulmány annak, ahogyan az egyedi projektek vezetésére vonatkozó tudás átvihető a projektprogramok vezetésének gyakorlatába.

\section{Felhasznált irodalom}

Andersen - Grude - Haug (2004): Goal Directed Project Management. $4^{\text {th }}$ ed., Kogan Page, London

Aubry - Hobbs - Thuillier (2007): A new framework for understanding organisational project management through the PMO. in: International Journal of Project Management, vol. 25, pp. 328-336.

Blomquist - Müller (2006): Practices, Roles, and Responsibilities of Middle Manager in Program and Portfolio Management. in: Project Management Journal, vol. $37,1$.

Gareis (2004): Happy Projects! Manz, Wienna

Görög (1996): Általános projektmenedzsment. Aula Kiadó, Budapest

Görög - Smith (1999): Project Management for Managers. PMI Publication, Sylva, NC

Görög (2000): Providing a Link between Strategic Objectives and Projects. in: Journal of European Business Education, vol. 10, 1.

Görög (2003): A projektvezetés mestersége. Aula Kiadó, Budapest

Heumann - Keegan - Turner (2007): Human resource management in: The project-oriented company: 
A review. in: International Journal of Project Management, vol. 25, pp. 315-323.

Hobbs - Aubry (2007): A Multi-Phase Research Program Investing Project Management Offices (PMO): The Results of Phase 1. in: Project Management Journal, vol. 38, 1.

Letavec (2006): The Program Management Office: Establishing, Managing and Growing the Value of a PMO. Ross Publishing

Maylor et al (2006): From projectification to programmification. in: International Journal of Project Management, vol. 24, pp. 663-674.

Martinsuo - Lehtonen (2007a): Role of single-project management in achieving portfolio management efficiency. in: International Journal of Project Management, vol. 25, pp. 56-65.

Martinsuo - Lehtonen (2007b): Program and its initiation in practice: Development program initiation in a public consortium. in: International Journal of Project Management, vol. 25, pp. 337-345.

Morris - Jamieson (2005): Moving from Corporate Strategy to Project Strategy. in: Project Management Journal, vol. 36, 4 .
Pellegrinelli et al. (2007): The importance of context in programme management: An empirical review of programme practices. in: International Journal of Project Management, vol. 25, pp. 41-55.

Rad - Levin (2006): Project Portfolio Management: Tools and Techniques. IIL Publishing

Thiry (2004): Programme management: a strategic decision management process. in: Morris PWG - Pinto JK, editors. The Wiley guide to project management. Wiley and Sons, New York

Thiry (2006): Managing portfolios of projects. in: Turner JR, editor. Gower handbook of project management. Gower Publishing, Aldershot

Thiry - Deguire (2007): Recent developments in project based organisations. in: International Journal of Project Management, vol. 25, pp. 649-658.

Turner - Speiser (1992): Programme management and its information systems requirements. in: International Journal of Project Management, vol. 10, pp. 196-206.

Cikk beérkezett: 2008. 5. hó

Lektori vélemény alapján véglegesítve: 2008. 6. hó

\section{AJÁNLÁS SZERZŐINKNEK}

A Vezetéstudomány a Budapesti Corvinus Egyetem Corvinus School of Management havi folyóirata. A lapban a vezetési és gazdálkodási tudományterületekhez kapcsolódó témakörök elméleti és gyakorlati kérdéseit elemző és vizsgáló írások jelennek meg. A szerkesztőség (robert.becsky@ uni-corvinus.hu) elektronikus formában kéri az írásokat. A cikkeket elektronikus levélben vagy mágneslemezen (MS Word fájl formátumban) lehet a szerkesztőséghez eljuttatni.

A lap tudományos folyóirat, ezért szövegközi forráshivatkozások és ezek jegyzéke nélküli írásokat nem jelentet meg. A Vezetéstudományban megjelentetni szándékozott kéziratok szerzőitől az alábbi követelmények figyelembevételét kérjük:

A cikkek szokásos terjedelme a hivatkozásokkal, ábrákkal és táblázatokkal együtt 20-24 oldal, 1,5-es sortávolsággal (12-es betűméret, Times New Roman betútípus). A cikkek első oldalának alján tüntessék fel a szerző foglalkozását, munkahelyét és beosztását, elektronikus levelezési címét, a tanulmány elkészítésével kapcsolatos információkat és az esetleges köszönetnyilvánításokat.

A kézirathoz csatolandó egy magyar nyelvú és egy angol nyelvű rövid összefoglaló (200 szót nem meghaladó terjedelemben), valamint a cikk fő témaköreit megnevező kulcsszavak jegyzéke.

Kiemeléshez félkövér és dólt betű használható, aláhúzás nem. Jegyzeteket lehetőleg ne használjanak, amennyiben azok feltétlenül szükségesek, szövegvégi jegyzetként adják meg.

A táblázatoknak és ábráknak legyen sorszáma és címe, valamint - átvett forrás esetén - pontos hivatkozása. Az ábrákat és a táblázatokat a kézirat végén, külön oldalakon, sorszámmal és címmel ellátva kérjük csatolni, helyüket a szövegben egyértelmúen jelölve (pl. „Kérem az 1. táblázatot kb. itt elhelyezni!").

A szövegközi bibliográfiai hivatkozásokat zárójelben, a vezetéknév és az évszám feltüntetésével kérjük jelölni: pl. (Veress, 1999); szó szerinti, idézójeles hivatkozás esetén kiegészítve az oldal(ak) számával (pl. Prahalad és Hamel, 1990:85). Amennyiben egy hivatkozott szerzőnek több bibliográfiai tétele van ugyanazon évben, ezeket 1999a, 1999b stb. módon kell megkülönböztetni.
A felhasznált források cikk végén elhelyezett jegyzékét ábécérendben kérjük, a következő formában: Szerző (évszám): Cím, kiadás helye: kiadó; illetve forrás.

1. példa (könyv): Porter, M. E. (1980): Competitive Strategy; New York: The Free Press.

2. példa (folyóiratcikk): Prahalad, C. K. és G. Hamel (1990): The Core Competence of the Corporation; Harvard Business Review, májusjúnius, 79-91. o.

A formai követelmények fentiekben érvényesített, ún. „Harvard” rendszeréről (más néven „,szerző/év” vagy „,név/dátum” hivatkozási módszerről) részletes tájékoztatást nyújtanak az alábbi WEB-címeken elérhető források.

Az elektronikus forrásokra való hivatkozás aktuális probléma. Az Internet Library for Librarians egyik polca (www.itcompany.com/inforetriever/ inetcite.htm) kilenc helyet gyưjjtött össze e témával kapcsolatban.

Az angolszász országokban több elterjedt formája van a bibliográfiai hivatkozásnak. Ezek a formák több folyóiratban is használatosak. Közülük az ún. Harvard-stílusú bibliográfiai hivatkozások vonatkozásában ad hasznos tanácsokat a Guide to Citing Internet Sources (www.bournemouth.ac.uk/ service-depts/lis/LIS_Pub/harvardsystint.html).

A Modern Language Association of America (MLA) - egyébként szintén sok helyütt alkalmazott - hivatkozási stílusával kapcsolatban ajánlható az MLA-Style Citations of Electronic Sources (www.cas.usf.edu/english/ walker/mla.html).

Az APA Publication Manual Crib Sheet (www.gasou.edu/psychweb/ tipsheet/apacrib.htm) az American Psychological Association (APA) idézési stílusával foglalkozó forrásokat gyújiti csokorba.

Havi folyóirat lévén és a megjelenés átfutási idejének csökkentése érdekében a Vezetéstudomány kefelevonatot nem küld, elfogadás elő́tt azonban a szerzóknek egyeztetés céljából elküldi a cikk szerkesztett változatát.

2006 januárjától az új lapszámok cikkeit és 2004-ig visszamenóleg az összes korábbi kiadás publikációit - külön kívánságra - elektronikus változatban is hozzáférhetôvé tesszük. 